\title{
THE ROLE OF PHYSICAL EDUCATION AND SPORT IN A CEREBRAL PALSY SCHOOL AND THE INTERACTION OF THERAPISTS AND PHYSICAL EDUCATIONISTS
}

M. M. VAN DER SPUY, M.C.S.P., O.N.C., J. GOOD, Dip. Physio. (U.C.T.), D.T.S.E. G. LIDDLE, Dip. Physio. (U.C.T.), D.T.S.E., B. SCOBLE, B.Sc. (Physio.) (Wits.)*

\section{OPSOMMING}

Die funksies van terapeute en liggaamlike opvoedkundiges in skole vir serebraalverlamdes word omskryf. Samewerking tussen terapeute en liggaamlike opvoedkundiges in die seleksie van sportaktiwiteite en posisionering van elke serebraalverlamde kind word beklemtoon. Die adolessente en volwasse serebraalverlamde het die reg om te besluit aan watter aktiwiteite hy wil deelneem, maar moet op die nadelige gevolge en fisiese agteruitgang wat verkeerde aktiwiteite tot gevolg mag hê, gewys word. Die voor- en nadele van verskeie sportaktiwiteite word bespreek.

In order to clarify some misconception about the role of sport and physical education in a cerebral palsy school; it is necessary to define the aims of physical education and sport, and decide whether the methods of applying these aims are suitable for the physically handicapped, cerebral palsied child.

\section{AIMS:}

- Physical fitness and the development of agility, flexibility, strength and stamina.

- Movement development, i.e. the learning of new movement skills or patterns.

- Emotional and social well-being through self-achievement, competition and team spirit.

- Intellectual development - by way of physical education.

* Department of Physiotherapy, Vista Nova School for Cerebral Palsied Children.

Received 25 September 1980.

\section{SUMMARY}

The rôles of therapists and physical educationists in cerebral palsy schools are described. Cooperation between therapists and physical educationists in selecting sporting activities and positioning of each individual cerebral palsied child is emphasised. The adolescent and adult cerebral palsied have the right to decide in which activities he wishes to participate, but the adverse effects and physical deterioration that can result from incorrect activities, should be pointed out. The advantages and disadvantages of different sporting activities are discussed.

One can see that there should be no difficulty in applying these aims to the psycho-neurologically disturbed (P.N.D.) or minimal cerebral dysfunction (M.C.D.) child, or to the child who is really minimally cerebral palsied (M.C.P.). This is said with certain qualifications, which we shall enlarge on later. It is also possible to apply them to the child with physical handicaps resulting from spinal or peripheral neurone damage such as paraplegia, poliomyelitis and even spina bifida in the absence of cerebral involvement.

To some extent the problem which we are about to discuss has arisen because of the exciting development of sport for the disabled which has taken place over the years, originating at the famous Stoke Mandeville Hospital, where one had the type of patient to whom the above aims would apply, with modifications. However, most of the children with physical handicaps in our South African cerebral palsy schools are there because of brain damage. They are referred directly, or indirectly, by the doctor who diagnosed the condition; to a special school where he expects that the child will receive the necessary remedial therapy, 
This is where a conflict of interest arises. On the one hand is the therapist, usually the physiotherapist or occupational therapist, whose main aim is to normalise the child's abnormal tone and improve the range and quality of movement patterns, allowing the child greater mobility and independence. Using specialised techniques, requiring direct handling of the child, the therapist endeavours to give the child a more normal sensorimotor experience.

On the other hand is the physical educationist, whose basic training equips him/her with the best methods of teaching the average child how best to achieve the peak of physical fitness and skill. Such children, without physical handicaps resulting from brain damage, may range from being clumsy to very agile. However, when these same methods are applied to the cerebral palsied child with physical handicaps arising from brain lesions, they may well have the opposite effect and could actually be detrimental to the child's physical development. Effort, increased speed, emotional stress and excitement lead to an increase in muscle tone in spastic children, whose muscle tone is already abnormally high. The same factors cause an increase in involuntary movements in athetoid children, increasing their instability and lack of co-ordination and thus reducing their functional ability.

In a cerebral palsy school the handicapped children are carefully assessed by the medical and paramedical team, and receive daily individual therapy according to their specific needs. The physical educationist usually gives physical training in groups and if the cerebral palsied child is treated in this way, it becomes very difficult to supervise each child adequately in order to prevent them from using bad patterns of movement. (The exception would be where Peto techniques were being applied, which is usually the responsibility of the physiotherapist). One can quite definitely state that it is impossible to apply the usual method of giving exercises to handicapped, cerebral palsied children (even ambulant, less affected children such as hemiplegics) without making extensive adaptations. Pupils for each class would then have to be carefully selected to make a homogenous group. This requires the specialised knowledge of the therapist, who probably would not take cerebral palsied children in groups unless there was a shortage of therapists.

Logically, if the child is receiving individual therapy, this should be sufficient exercise. The cerebral palsied child is invariably taken out of class for more than one type of therapy during the day and teachers, therefore, complain that they do not have enough time in the day to get through the syllabus.

The employment of physical education teachers in cerebral palsy schools is a fairly recent development necessitated by the admission of increasing numbers of children with M.C.D. (specific learning disabilities) many of whom are clumsy and in need of extra attention from the physical educationist. This relieves the therapists, who are not adequately trained to conduct conventional gym classes, of a considerable amount of work.

Different age groups, languages, sexes and handicaps in relatively small schools, such as cerebral palsy schools, all compound the problem for the physical educationist of getting a well-matched group together. Therefore, as fur as physical education for cerebral palsied children is concerned, it would seem better that it is reserved for those with M.C.D. or M.C.P.; in the last instance only if it can be ensured that, if the child has spasticity, it is not increased with uncontrolled effort.

As far as sport is concerned, physically handicapped and cerebral palsied children have the same social and psychological needs as other children. The aims of selfacilievement and team spirit may be fulfilled through sport and games, but the important physical factors already mentioned should be remembered. Each child should be carefully analysed and put into a group, according to his ability. Classification for athletics meetings in cerebral palsy schools would, of necessity have to be on a more general basis, because there are a limited number of spastic hemiplegics, diplegics and quadriplegics, athetoids and ataxics in each school Therefore, it seems advisable to divide them into nursery, junior and senior groups, according to age and sub-divide these groups into as many groups based on ability, e.g. very handicapped, moderately handicapped and minimally handicapped. For inter-school sports meetings it may be possible to classify children according to their specific handicap as well as their ability within that handicap.

How many non-handicapped people live perfectly happy and contented lives, without ever actively competing in sport? Perhaps too much emphasis is placed on sport for the handicapped? What about group participation in chess tournaments, music clubs, book clubs?

The problem of competitive sport and classification dealt with in a recent article by Köng (1979b). The emphasis here is on individual achievement as was done at the recent international games in Magglingen. Certificates were awarded for individual achievement and attendance. Group activities were used for pleasure rather than on a competitive basis. While in practice it is difficult to eliminate competition, Dr. Köng seems to have outlined the solution to this complex problem.

It is the therapists' concern to sort out the "minimals" from the physically handicapped and recommend the different types of sports and games suitable for each individual child. Once this has been done, the physical educationist has the advantage of specialised knowledge of how to teach the chosen sport or game.

With adequate consultation between the therapist concerned and the physical educationist, there should be no problem in choosing suitable games and sports for cerebral palsied children. Special attention should be given to individual conditions. Ensure that each child is moving in as, or near as, a natural way as he can.

Most suitable sports are performed from a sedentary or standing position. Some of these may be horseriding (Sampson, 1979), carpet bowls, croquet, archery, skittles, shuffleboard, darts, table tennis, shotput, discus and javelin. Cycling, supervised swimming in water which is not too cold (Harris, 1978), and even snowskiing (Köng 1979a) may be included. For some of thes sports, intensive preparation is required, if the child to be able to achieve his optimal potential; no child should be introduced to a new sport without prior discussion with the therapist in order that she can prepare him with the movement patterns required for that sport. At athletics' meetings, team races can include sitting astride a long bench passing a ball or a baton along, or standing doing the same.

Sports which are unsuitable for cerebral palsied children are any sports which include running, e.g. races, tennis, soccer, netball, hockey, cricket. This applies mainly to the spastics. The excessive effort and increased speed involved in a running race will tend to increase spasticity. Young children should not be encouraged in activities which may harm them in later life. Later, of course, a choice of sport becomes a personal decision but the pitfalls should be stressed in terms of increase in tone and associated reactions, which could lead to physical deterioration.

Many people, without the problem of cerebral palsy, develop osteo-arthritis in middle age because of stress to certain joints which are at risk because of sporting or occupational habits. It so often happens that cerebral palsied adults in their twenties, especially diplegics and hemiplegics, develop osteo-arthritis in their lumbar 
spines, hips, knees or joints of their feet because of the unnatural positions which their joints must assume during walking. This places a stress on joints which were made to function in a different pattern. It may be assumed that the stress of competitive running would only aggravate the problem. This would be in addition to all its other contra-indications.

Another contra-indication to running races is the sheer embarrassment of falling in front of a large audience. This can be a very traumatic emotional experience for an adolescent and, if only for this reason, many therapists would agree that no child should participate in sport involving running, but one cannot gainsay the enjoyment which the older hemiplegics get from sports such as netball, football and cricket, and in these cases one should not be dogmatic but allow them to decide for themselves. As far as these running sports are concerned. hockev would seem to be the most acceptable sport because it necessitates bilateral arm use throughout the game. This inhibits the asymmetrical tonic neck mflex and associated reactions of the affected arm, as ll as retraction of the head and shoulder girdle to a certain extent. If the child cannot maintain his grip on the hockey stick with the hemiplegic hand, it would be easy to make a velcro strap which would hold the affected hand in contact with the stick. This encouragement of midline use of the arms would be beneficial to athetoids for similar reasons, the main one being reduction of asymmetry.

Other sports which would be contra-indicated are one-handed activities such as tennis and table tennis for children with obvious asymmetry. As far as throwing events such as shotput, discus and javelin are concerned, it is possible to inhibit the affected or more affected side by making the child place that hand on the knee during throwing. One should also ensure that the weight is not too heavy or this would increase asymmetry.

Another type of racing which has been included in some cerebral palsy schools athletics' meetings in the past, has been the wheelchair race. This is, of course, an offshoot of the Paraplegic Games. This, again, is contra-indicated for spastics because downward pressure of the arms on the wheels plays into the pattern of spasticity and increases it (in the same way as downward pressure of the arms in the use of walking sticks and crutches, increases spasticity). For this reason, sport which involves pulling activities such as tug-of-war, ould also be avoided. There are many throwing or shing activities available which are preferable.

Whether a child is severely handicapped or not, an endeavour should be made to achieve as near normal a pattern as possible during movement. This can be done by the choice of a good starting position. In selecting this a very intimate knowledge of the child's problems is necessary. Once again, the importance of consultation between the therapist and physical educationist must be stressed.

Perhaps sufficient thought is not always given to the eventual effect on classroom achievement. As spasticity increases in the legs, extension and rotation of the trunk and pelvis will become more difficult. This will lead to a deterioration in equilibrium reactions, which causes a greater dependence on the arms for balance. This, in turn, will cause a deterioration in arm function as the arms are no longer free. Quality of writing will be affected and the threat to the child's educational potential must be obvious.

In the school situation, it is felt that athletics meetings play a vital part in allowing children to identify with each other through team spirit. It is most important to give everyone, no matter how physically handicapped, a chance to be part of the scene! This has been shown to be possible.

\section{CONCLUSION}

In a school for the cerebral palsied, where both physiotherapists and physical educationists are present, there appear to be clearly defined roles. The physiotherapist is responsible for the physical well-being of the cerebral palsied child. Individual treatment is given, aimed at normalisation of postural tone and movement. The physical educationist should take care of groups of children whose muscle tone is relatively normal, i.e. the clumsy children or the P.N.D. children.

When the cerebral palsied child wishes to participate in sporting activities, the activity should be carefully selected for the particular child. The physical educationist and physiotherapist should consult as regards suitable positioning of the child.

The adolescent and adult cerebral palsied person obviously has the right to decide for himself in which he wishes to participate, but he must be warned that this may contribute to his physical deterioration/detriment. Thus the authors feel that physical education is not indicated for the cerebral palsied child. Suitable sporting activities, with adequate supervision, are allowable.

\section{References}

Anonymous (1979) Athletics for the cerebral palsied child. S.A.C.P. Journal 22, 3, $11-12$.

Harris, S. R. (1978). Neurodevelopmental treatment for teaching swimming to cerebral palsied children. Phys. Ther. 58, 979 - 983.

Huberman, G. (1974). Organised sports activity with spastic adolescents. International C.P.S. Bulletin "Autumn". Reprinted in S.A.C.P. Journal March $1975,3-5$

Huberman, G. (1976). Organised sports activities with cerebral palsied adolescents. Physiotherapy 62, 362 363.

Irwin-Carruthers, S. and Richardson, E. (1976). A preliminary investigation into sport for the cerebral palsied school child. S.A.C.P. Journal 20, $21-25$.

Köng, E. (1979a). Skiing with cerebral palsied children - experiences in Switzerland. S.A. Journal of Physiotherapy 35, 8 - 10.

Köng, E. (1979b). Attitude on competitive sport cerebral motor disturbances. Mitterlungsblatt der Schweizerischer Bund der Therapeuten Cerebralen Bewegingsstörungen 20, 5. Reprinted in newsletter 3, 2 of S.A.N.D.T.A.

Sampson, B. (1979). Riding for the disabled. S.A. Journal of Physiotherapy 35, 6-8. 